\title{
Communication and Relationships Factors of Pharmacy Career Satisfaction in Saudi Arabia
}

\begin{abstract}
Yousef Ahmed Alomi* iD, The
Former General Manager of General Administration of Pharmaceutical Care, Former Head, National Clinical Pharmacy and Pharmacy Practice, Former Head, Pharmacy R\&D Administration, Ministry of Health, Riyadh, SAUDI ARABIA.

Faiz A. Bahadig, Informatics Pharmacist, Pharmaceutical Care Department, King Abdul-Aziz Medical, City-WR-Jeddah, Ministry of National Guard, SAUDI ARABIA Saima Qaism, Senior Pharmacist, Pharmaceutical Care Department, King Abdul-Aziz Medical City-Jeddah, Ministry of National Guard, SAUDI ARABIA.

Khurram Shahzad, Senior Pharmacist, Pharmaceutical Care Department, King Abdul-Aziz Medical City-Jeddah, Ministry of National Guard, SAUDI ARABIA. Budoor Emad Aloumi, Pharmacist, Pharmaceutical Care Services, Ministry of National Guard - Health Affairs. KAMC Central Region, SAUDI ARABIA.

Bayan Ibrahim Alghuraybi, Pharmacy Services, Prince Sultan Military Medical City, Riyadh, SAUDI ARABIA.

Reem Saad Alsubaie, Pharmacy Services, Prince Sultan Military Medical City, Riyadh, SAUDI ARABIA.
\end{abstract}

\section{Correspondence:}

Yousef Ahmed Alomi, The Former General Manager of General Administration of Pharmaceutical Care, Former Head, National Clinical Pharmacy and Pharmacy Practice, Former Head, Pharmacy R\&D Administration, Ministry of Health, Riyadh-11564, SAUDI ARABIA.

Phone no: +966 504417712

E-mail:yalomi@gmail.com

Received: 02-01-2019;

Accepted: 24-04-2019

Copyright: $\odot$ the author(s),publisher and licensee Pharmacology, Toxicology and Biomedical Reports. This is an open-access article distributed under the terms of the Creative Commons Attribution NonCommercial License, which permits unrestricted non-commercial use, distribution, and reproduction in any medium, provided the original work is properly cited.

This is an open access article distributed under the terms of the Creative Commons Attribution-NonCommercial-ShareAlike 4.0 License

Access this article online

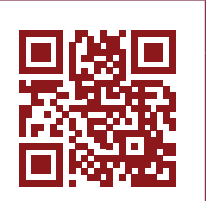

www.ptbreports.org

DOI:

10.5530/PTB.2019.5.23

\begin{abstract}
Objectives: This article describes the overall job satisfaction of pharmacists working in Saudi Arabia by exploring their communication and relationship with supervisors and patients. The aim of this study to declare the communications and relationship factors of Pharmacist Job satisfaction in Saudi Arabia. Methods: This is a 4-months cross section survey of communication and relationship factors on Pharmacist Job satisfaction in Saudi Arabia. The study consisted of forty-three questions divided into two-part demographic information and the second part was the questions about communication and relationships factors of pharmacy job. It included pharmacy supervisors, relationship with coworkers and pharmacist interaction with other healthcare providers, the customer interaction and overall job satisfaction. Results: The total responders were two hundred and forty-two. The gender distribution $169(70.7 \%)$ was male and 70 (29.3\%) was female. The majority of them 202 (84.2\%) were in age (20-39). The average satisfaction score of pharmacy supervisors' factors was (3.0), pharmacist interaction with other healthcare providers' factors was (3.34) while the customer interaction was (2.81) and the pharmacist relationship with coworkers was (3.67). Most of the pharmacist found the challenges at their job were (77.6\%). Some responders wished to change their pharmacy career $(43.75 \%)$ while $(61.66 \%)$ liked to stay in the pharmacy field. The overall job satisfaction scores were (3.61). Conclusion: Most of the pharmacists not satisfied with their job because of the supervisor relationship and non-existent patient education services. The pharmacy supervisors of hospital pharmacies demanded management tools and communication skills with their colleagues. In addition, patient counselling program should be implemented at healthcare institutions in Saudi Arabia

Keywords: Communication, Relationships, Factors, Pharmacy, Career, Satisfaction, Saudi Arabia.
\end{abstract}

\section{INTRODUCTION}

The health care system in Saudi Arabia is advanced and well-structured including pharmacy services, where the employment sectors include the Ministry of Health, Non-MOH, University, private healthcare, community pharmacies, the pharmaceutical industry and other facilities. ${ }^{1}$ The professional pharmacist interacted closely with other medical health care professionals in hospitals and with the patients; hence, the significance of pharmacists in a multidisciplinary team has increased. As part of a team providing health services, pharmacists are a participant in fulfilling various tasks and in making decisions that have an impact on a patient's quality of life. ${ }^{2}$ As a result, an employee's feeling towards his/her job plays a vital role in work motivation, satisfaction and retention.

Job satisfaction is an essential factor for increasing a person's involvement in the workplace. Satisfaction has been linked positively to motivation, performance, productivity, organizational commitment and patient safety. ${ }^{3}$ Several factors that may affect job satisfaction are proper management, good relationships with co-workers, regular working hours and compensation. One of the critical factors associated with employee's job satisfaction is communication. The communication impacts an employee's job situation and can decrease an employee's uncertainty. Communication is also a multidimensional concept and communication factors responsible for employ- ee's job satisfaction are role expectations, social support, leadership and justice. The furthermost determinant factors for job satisfaction have been known as job interestingness, relationships with managers and colleagues, high income and evidently definite career advancement opportunities. Employees are more satisfied when they are supported by their co-workers and superiors, have an understanding of the precise role of their job, have superiors that are ready to help them and affect them in the right way and are informed of critical decision making within the hospital. It should keep the employees glad and satisfied at work as it influences productivity and patient satisfaction. ${ }^{4}$

On the other hand, poor job satisfaction directly impacted performance, especially for pharmacists. These performance problems can include medication error like an error in prescription, dispensing, or administration, not detecting drug interactions and inadequate patient counseling. It is essential to realize that a decrease in pharmacist performance could cause patient harm or even death. As a result, the dissatisfaction may also affect the way that patients views the pharmacist and therefore, may limit their interactions with the pharmacist. If pharmacists are dissatisfied with their career, they are more likely to resign. Pharmacist job satisfaction does affect the pharmacist at the workplace, besides this may potentially affect many other aspects of the phar- 
macist's life. ${ }^{5}$

The authors based on their knowledge are familiar with few investigations in the Kingdom of Saudi Arabia (KSA) about communication factors with supervisors or coworkers or healthcare providers that affected positively or negatively on pharmacist job satisfaction. ${ }^{6,7}$ This study will celebrate association of many factors which related to pharmacist job satisfaction linked such as relation with health care practitioners like nurse and physicians. Moreover, challenging tasks for pharmacists never stop. As professional members of the health care team, pharmacists must exhibit positive relation with colleagues and staff. Pharmacist relationship with patient as customer is another important task as far job responsibilities are concerned.

\section{METHODS}

It is a 4-months cross sectional survey of communication and relationship factors on Pharmacist Job satisfaction in Saudi Arabia. The study consisted of 34 questions divided into two parts, demographic information and the second part was the questions about communication and relationship factors of pharmacy job. It included pharmacy supervisors, relationship with coworkers and pharmacist interaction with other healthcare providers, customer interaction and overall job satisfaction. A 5-point Liker-type scale was used. There were open and closed-ended questions. The survey made as an electronic format and it analyzed through survey monkey system.

\section{RESULTS}

The total responders were 242. Of those 214 (91.8\%) were from Saudi and $33(8.2 \%)$ were from other countries. The gender distribution 169 $(70.7 \%)$ was male and $70(29.3 \%)$ was female. The majority of them 202 (84.2\%) were in age (20-39). Most of the pharmacists were married 152 (66.38\%) while $75(32.75 \%)$ were singles (Table 1$)$.

The most educational level of the responders was a bachelor degree in pharmacy 114 (47.7\%), followed by pharmacy diploma level was 81 (33.89\%) and Pharm.D 26 (10.88\%). Most of the responders has not board of pharmaceuticals 171 (93.44\%). Most of the current positions were held by pharmacy technicians $80(34.93 \%)$ and staff pharmacist 78 (34.5\%) and worked at outpatient pharmacy 83 (39.7\%) and inpatient pharmacy $73(34.9 \%)$. Most of the responders spent less than $2(30 \%)$, followed by three years, three to five years $61(24.42 \%)$ and six to ten years $50(20.83 \%)$ working in the current position. While more of responders receive 7,000 - 12,000 SR monthly salary 138 (58.97\%) (Table 2).

Most of the responders worked at Ministry of health 103 (42.92\%) followed by $\mathrm{MOH}$ government Hospital 66 (27.5\%) and Non- MOH government Hospital 31 (12.92\%). The responders worked at (200-299 beds) 32 (17.02\%) followed by (100-199 beds) 31 (16.49\%) and $(<50$ beds) 29 (15.43\%). Most hospitals were accredited by Saudi Commission for Health Specialties 97 (48.74\%) followed by Saudi Central Board for Accreditation of Healthcare Institutions (CBAHI) 58 (29.15\%) and Joint commission of hospital accreditations USA 40 (20.1\%) (Table 3). The average satisfaction score of pharmacy supervisors' factors was (3.0), pharmacist interaction with other healthcare providers' factors was (3.34) (Table 4 and 5). While the customer interaction was (2.81) the pharmacist relationship with coworkers was (3.67). Most of the pharmacists found the challenges at their job (77.6\%). Some responders wished to change their pharmacy career $(43.75 \%)$ while $(61.66 \%)$ liked to stay in the pharmacy field. The overall job satisfaction scores were (3.61) (Table $6)$.

\section{DISCUSSION}

The primary purpose of the present study was to explore the communication and relationships factors of pharmacy career satisfaction in Saudi Arabia. The reason for these aims was efforts should be made to raise the levels of job satisfaction for pharmacists to improve their motivation and competence and to reduce stress among workers which puts both pharmacists and patients at safe side. The results from this study indicate that most pharmacists in Saudi Arabia found the challenges in their jobs. One of the causes of these challenges for pharmacists in their careers was the supervisors' relationship with employees. The pharmacists confirm in this study that most of the supervisors did not support them. Also, they have no superiors that are ready to help them and affect them in the right way and teach them how to properly deal with various types of patients. These results are in line with previous studies as they have justification when employee's job roles are not clear; they are more likely to be dissatisfied with their jobs. ${ }^{4}$ The majority of respondents reported the supervisors don't give adequate consideration to their complaints and respond to them, previous study ${ }^{8}$ justify this negative reason. The only possible explanation to that is the individual variation that might exist from one pharmacist to the other and the uniqueness of each case. Besides the results of this study, pharmacists face challenges with physicians, where

Table 1: Demographic social information.

\begin{tabular}{|c|c|c|}
\hline Nationality & Response Count & Response Percent \\
\hline Saudi & 214 & 91.85 \\
\hline Non-Saudi & 19 & 8.15 \\
\hline Answered question & 233 & \\
\hline Skipped question & 9 & \\
\hline Gender & Response Count & Response Percent \\
\hline Male & 169 & 70.71 \\
\hline Female & 70 & 29.29 \\
\hline Answered question & 239 & \\
\hline Skipped question & 3 & \\
\hline Age & Response Count & Response Percent \\
\hline$<19$ & 0 & 0 \\
\hline $20-29$ & 87 & 42.08 \\
\hline $30-39$ & 86 & 42.08 \\
\hline $40-49$ & 26 & 12.92 \\
\hline $50-59$ & 6 & 2.92 \\
\hline$>60$ & 0 & 0 \\
\hline Answered question & 240 & \\
\hline Skipped question & 2 & \\
\hline Marital status & Response Count & Response Percent \\
\hline Single & 75 & 32.75 \\
\hline Married & 152 & 66.38 \\
\hline Other (please specify) & 2 & 0.87 \\
\hline Answered question & 229 & \\
\hline Skipped question & 13 & \\
\hline
\end{tabular}


Table 2: Demographic responder qualifications information.

\begin{tabular}{|c|c|c|}
\hline Academic Qualification (s): & Response Count & Response Percent \\
\hline Diploma Pharmacy & 81 & 33.89 \\
\hline Bsc. Pharm & 114 & 47.70 \\
\hline M.S & 4 & 1.67 \\
\hline Msc. Clinical Pharmacy & 16 & 6.69 \\
\hline Pharm.D. & 26 & 10.88 \\
\hline Ph.D & 2 & 0.84 \\
\hline MBA & 4 & 1.67 \\
\hline $\begin{array}{l}\text { Pharmacy Residency Two years } \\
\left(R^{2}\right)\end{array}$ & 2 & 0.84 \\
\hline $\begin{array}{l}\text { Pharmacy Residency one year } \\
\text { (R1) }\end{array}$ & 2 & 0.84 \\
\hline Fellowship & 0 & 0 \\
\hline Other (please specify) & 3 & 1.26 \\
\hline Answered question & 239 & \\
\hline Skipped question & 3 & \\
\hline $\begin{array}{l}\text { Board of Pharmaceutical } \\
\text { Specialty }\end{array}$ & Response Count & Response Percent \\
\hline $\begin{array}{l}\text { Board Certified Ambulatory } \\
\text { Care Pharmacist (BCACP) }\end{array}$ & 2 & 1.09 \\
\hline $\begin{array}{l}\text { Board Certified Critical Care } \\
\text { Pharmacist (BCCCP) }\end{array}$ & 3 & 1.64 \\
\hline $\begin{array}{l}\text { Board Certified Nuclear } \\
\text { Pharmacist (BCNP) }\end{array}$ & 0 & 0.00 \\
\hline $\begin{array}{l}\text { Board Certified Nutrition } \\
\text { Support Pharmacist (BCNSP) }\end{array}$ & 0 & 0.00 \\
\hline $\begin{array}{l}\text { Board Certified Oncology } \\
\text { Pharmacist (BCOP) }\end{array}$ & 0 & 0.00 \\
\hline $\begin{array}{l}\text { Board Certified Pediatric } \\
\text { Pharmacy Specialist (BCPPS) }\end{array}$ & 0 & 0.00 \\
\hline $\begin{array}{l}\text { Board Certified } \\
\text { Pharmacotherapy Specialists } \\
\text { (BCPS) }\end{array}$ & 2 & 1.09 \\
\hline $\begin{array}{l}\text { Board Certified Psychiatric } \\
\text { Pharmacist (BCPP) }\end{array}$ & 1 & 0.55 \\
\hline Non & 171 & 93.44 \\
\hline Other (please specify) & 4 & 2.19 \\
\hline Answered question & 183 & \\
\hline Skipped question & 59 & \\
\hline Current position & Response Count & Response Percent \\
\hline Pharmacy Technicians & 80 & 34.93 \\
\hline Lecturer & 0 & 0.00 \\
\hline Intern Pharmacist & 3 & 1.31 \\
\hline Director of Pharmacy & 22 & 9.61 \\
\hline Staff Pharmacist & 79 & 34.50 \\
\hline
\end{tabular}

\begin{tabular}{|c|c|c|}
\hline Supervisor Pharmacist & 21 & 9.17 \\
\hline Clinical Pharmacist & 12 & 5.24 \\
\hline Deputy Director of Pharmacy & 4 & 1.75 \\
\hline Manager & 3 & 1.31 \\
\hline Other (please specify) & 5 & 2.18 \\
\hline Answered question & 229 & \\
\hline Skipped question & 13 & \\
\hline The practice area & Response Count & Response Percent \\
\hline Inpatient Pharmacy & 73 & 34.76 \\
\hline Outpatient Pharmacy & 83 & 39.52 \\
\hline Satellite Pharmacy & 0 & 0.00 \\
\hline Narcotics & 2 & 0.95 \\
\hline Extemporaneous Preparation & 2 & 0.95 \\
\hline Clinical Pharmacy & 9 & 4.29 \\
\hline Inventory Control & 3 & 1.43 \\
\hline Drug Information & 4 & 1.90 \\
\hline Emergency pharmacy & 2 & 0.95 \\
\hline Medication safety & 2 & 0.95 \\
\hline Repacking & 0 & 0.00 \\
\hline $\begin{array}{l}\text { Pharmacy Education and } \\
\text { Training }\end{array}$ & 1 & 0.48 \\
\hline Other (please specify) & 29 & 13.81 \\
\hline Answered question & 210 & \\
\hline Skipped question & 32 & \\
\hline $\begin{array}{l}\text { Total years you worked in } \\
\text { current position }\end{array}$ & Response Count & Response Percent \\
\hline$<3$ & 72 & 30.00 \\
\hline $3-5$ & 61 & 25.42 \\
\hline $6-10$ & 50 & 20.83 \\
\hline $11-15$ & 25 & 10.42 \\
\hline$>15$ & 32 & 13.33 \\
\hline Answered question & 240 & \\
\hline Skipped question & 2 & \\
\hline Monthly income & Response Count & Response Percent \\
\hline$<6.000$ & 16 & 6.84 \\
\hline $7.000-9.000$ & 56 & 23.93 \\
\hline $10.000-12.000$ & 82 & 35.04 \\
\hline $14,000-16,000$ & 43 & 18.38 \\
\hline $18,000-20,000$ & 26 & 11.11 \\
\hline$>25.000$ & 11 & 4.70 \\
\hline Answered question & 234 & \\
\hline Skipped question & 8 & \\
\hline
\end{tabular}


Table 3: Demographic hospital information.

\begin{tabular}{|c|c|c|}
\hline Sector of work & Response Count & Response Percent \\
\hline Ministry of Health & 103 & 42.92 \\
\hline $\begin{array}{l}\text { General Medical Directorate in } \\
\text { Region }\end{array}$ & 3 & 1.25 \\
\hline MOH government Hospital & 66 & 27.50 \\
\hline Non- MOH government Hospital & 31 & 12.92 \\
\hline MOH-Primary Care Center & 22 & 9.17 \\
\hline Private Hospital & 3 & 1.25 \\
\hline Private Primary Care Center & 0 & 0 \\
\hline Community pharmacy & 7 & 2.92 \\
\hline Other (please specify) & 5 & 2.08 \\
\hline Answered question & 240 & \\
\hline Skipped question & 2 & \\
\hline Number of beds at your hospital & Response Count & Response Percent \\
\hline$<50$ & 29 & 15.43 \\
\hline $50-99$ & 16 & 8.51 \\
\hline $100-199$ & 31 & 16.49 \\
\hline $200-299$ & 32 & 17.02 \\
\hline $300-399$ & 15 & 7.98 \\
\hline $400-499$ & 13 & 6.91 \\
\hline $500-599$ & 14 & 7.45 \\
\hline$=$ or $>600$ & 13 & 6.91 \\
\hline Medical City & 25 & 13.30 \\
\hline Answered question & 188 & \\
\hline Skipped question & 54 & \\
\hline The hospital accreditation & Response Count & Response Percent \\
\hline CBAHI & 58 & 29.15 \\
\hline Joint Commotion USA & 40 & 20.10 \\
\hline Canada & 4 & 2.01 \\
\hline $\begin{array}{l}\text { Saudi commission of health } \\
\text { accreditation }\end{array}$ & 97 & 48.74 \\
\hline Answered question & 199 & \\
\hline Skipped question & 43 & \\
\hline
\end{tabular}

some physicians are uncooperative when they must communicate with them about "job-related issues". Also, of the results most of the pharmacists in the present study they confirm satisfied with the good coworkers and have a good interpersonal relationship between pharmacists. The current study is similar to previous studies ${ }^{6,7}$ showed that the pharmacists who were confident with the coworkers as pharmacists confirm in this study patient's appreciation for the services provided to them and attempt to comply with the directions and advice given to them. After all, these reasons showed that there was a significant relationship between all of these factors and job satisfaction.
Table 4: Pharmacist satisfaction on supervisor's relationship.

\begin{tabular}{|c|c|c|c|c|c|c|c|c|}
\hline & Supervisors & 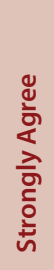 & 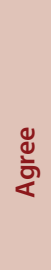 & $\begin{array}{l}\overline{\widetilde{J}} \\
\overline{\vec{J}} \\
\text { z }\end{array}$ & 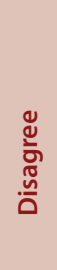 & 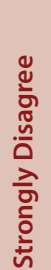 & 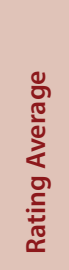 & 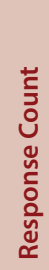 \\
\hline 1 & $\begin{array}{l}\text { My supervisors provide } \\
\text { competent and consistent } \\
\text { supervision. }\end{array}$ & 32 & 74 & 61 & 46 & 27 & 3.16 & 240 \\
\hline 2 & $\begin{array}{l}\text { My supervisors give me } \\
\text { a sufficient amount of } \\
\text { information (feedback) } \\
\text { about how well I am doing } \\
\text { my job. }\end{array}$ & 30 & 75 & 55 & 52 & 28 & 3.11 & 240 \\
\hline 3 & $\begin{array}{l}\text { My supervisors have an } \\
\text { adequate knowledge of their } \\
\text { jobs. }\end{array}$ & 21 & 63 & 79 & 49 & 28 & 3.00 & 240 \\
\hline 4 & $\begin{array}{l}\text { My supervisors give ample } \\
\text { consideration to employee } \\
\text { complaints and pharmacy } \\
\text { issues and respond to them } \\
\text { in a timely manner. }\end{array}$ & 21 & 74 & 42 & 65 & 37 & 2.90 & 239 \\
\hline 5 & $\begin{array}{l}\text { My supervisors teach } \\
\text { pharmacist the proper } \\
\text { dealing with various types of } \\
\text { patients. }\end{array}$ & 23 & 64 & 64 & 61 & 29 & 2.96 & 241 \\
\hline 6 & $\begin{array}{l}\text { My supervisors teach the } \\
\text { pharmacist professional } \\
\text { pharmaceutical / } \\
\text { management related skills. }\end{array}$ & 15 & 62 & 53 & 73 & 35 & 2.79 & 238 \\
\hline 7 & $\begin{array}{l}\text { My supervisors help the } \\
\text { pharmacist in identifying } \\
\text { potential unavailable } \\
\text { products in pharmacy but } \\
\text { available in warehouse or } \\
\text { other pharmacies. }\end{array}$ & 25 & 73 & 64 & 47 & 27 & 3.09 & 236 \\
\hline 8 & $\begin{array}{l}\text { My supervisor provides } \\
\text { constructive criticism to } \\
\text { employees. }\end{array}$ & 18 & 74 & 62 & 51 & 30 & 3.00 & 235 \\
\hline & Average & & & & & & 3.00 & \\
\hline
\end{tabular}

\section{CONCLUSION}

The pharmacist job satisfaction was inadequate. The supervisors did not support the pharmacist. The pharmacist had challenges in the pharmacy work with inadequate customer communication. Annual survey of Pharmacist job satisfaction with an emphasis on communication factors is highly recommended in the Kingdom of Saudi Arabia.

\section{ACKNOWLEDGEMENT}

None.

\section{CONFLICT OF INTEREST}

The authors declare that there are no conflicts of interest. 
Table 5: The pharmacist interaction with other healthcare providers' factors.

\begin{tabular}{|c|c|c|c|c|c|c|c|c|}
\hline & $\begin{array}{l}\text { Negative / Positive } \\
\text { interactions with health } \\
\text { care providers }\end{array}$ & 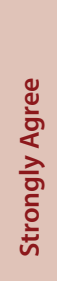 & ఫ্ঠ & $\begin{array}{l}\overline{\frac{\pi}{2}} \\
\frac{\bar{d}}{2} \\
\frac{0}{2}\end{array}$ & 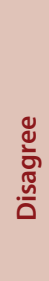 & 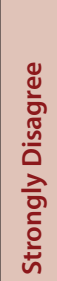 & 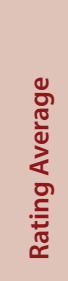 & 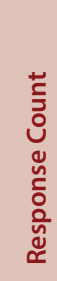 \\
\hline 1 & $\begin{array}{l}\text { Physicians are } \\
\text { uncooperative when I } \\
\text { must communicate with } \\
\text { them about "job-related" } \\
\text { matters. }\end{array}$ & 35 & 71 & 73 & 54 & 7 & 3.30 & 240 \\
\hline 2 & $\begin{array}{l}\text { Physicians consult with } \\
\text { me often on professional } \\
\text { matters. }\end{array}$ & 14 & 101 & 78 & 35 & 8 & 3.33 & 236 \\
\hline 3 & $\begin{array}{l}\text { Nurses are uncooperative } \\
\text { when I initiate } \\
\text { communication with } \\
\text { them about "job-related" } \\
\text { matters. }\end{array}$ & 17 & 57 & 63 & 83 & 14 & 2.91 & 234 \\
\hline 4 & $\begin{array}{l}\text { Nurses often initiate } \\
\text { consultation with me on } \\
\text { professional matters. }\end{array}$ & 27 & 104 & 68 & 24 & 11 & 3.48 & 234 \\
\hline 5 & $\begin{array}{l}\text { Non- pharmacists often } \\
\text { perform functions that } \\
\text { should only be performed } \\
\text { by a pharmacist. }\end{array}$ & 31 & 70 & 65 & 50 & 18 & 3.20 & 234 \\
\hline 6 & $\begin{array}{l}\text { Technicians are respected } \\
\text { by other health care } \\
\text { providers. }\end{array}$ & 26 & 98 & 54 & 35 & 23 & 3.29 & 236 \\
\hline 7 & $\begin{array}{l}\text { Technicians are } \\
\text { cooperative at the } \\
\text { pharmacy. }\end{array}$ & 62 & 113 & 37 & 20 & 5 & 3.87 & 237 \\
\hline & Average & & & & & & 3.34 & \\
\hline \multicolumn{9}{|c|}{ Answered questions 240, Skipped questions 2} \\
\hline
\end{tabular}

Table 6: The pharmacist relationship with Customers and coworkers.

\begin{tabular}{|c|c|c|c|c|c|c|c|c|}
\hline & Customer interactions & 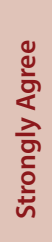 & ఖ & $\begin{array}{l}\overline{0} \\
\frac{\pi}{3} \\
\frac{0}{2}\end{array}$ & 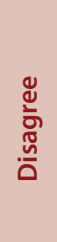 & 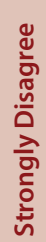 & 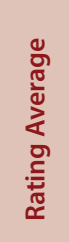 & 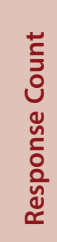 \\
\hline 1 & $\begin{array}{l}\text { Patients show appreciation } \\
\text { for the services I provide } \\
\text { for them. }\end{array}$ & 28 & 75 & 75 & 45 & 14 & 2.43 & 237 \\
\hline 2 & $\begin{array}{l}\text { In general, I find that } \\
\text { patients (customers) } \\
\text { attempt to comply with } \\
\text { the directions and advice I } \\
\text { give them. }\end{array}$ & 13 & 109 & 81 & 29 & 6 & 3.19 & 238 \\
\hline & Average & & & & & & 2.81 & \\
\hline \multicolumn{9}{|c|}{ Answered question 238, Skipped question 4} \\
\hline & $\begin{array}{l}\text { Relationships with } \\
\text { coworkers }\end{array}$ & 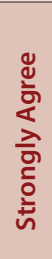 & ఖ & 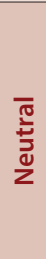 & 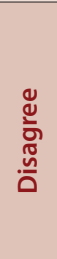 & 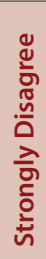 & 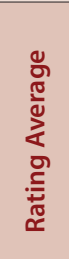 & 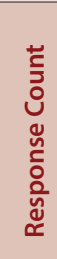 \\
\hline 1 & $\begin{array}{l}\text { The people with whom I } \\
\text { work are friendly. }\end{array}$ & 49 & 121 & 52 & 13 & 4 & 3.83 & 239 \\
\hline 2 & $\begin{array}{l}\text { I receive recognition and } \\
\text { a sense of personal worth } \\
\text { from my colleagues. }\end{array}$ & 58 & 117 & 45 & 14 & 2 & 3.91 & 236 \\
\hline 3 & $\begin{array}{l}\text { All of my coworkers in } \\
\text { the pharmacy are highly } \\
\text { competent. }\end{array}$ & 30 & 67 & 83 & 47 & 9 & 3.26 & 236 \\
\hline & Average & & & & & & 3.67 & \\
\hline \multicolumn{9}{|c|}{ Answered questions 239, Skipped questions 3} \\
\hline & Overall job satisfaction & 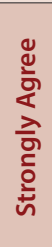 & ๗ँ & 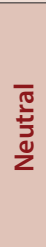 & 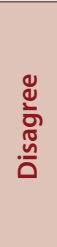 & 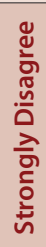 & 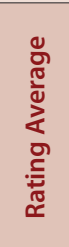 & 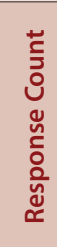 \\
\hline 1 & $\begin{array}{l}\text { I find challenge in my } \\
\text { work. }\end{array}$ & 87 & 100 & 32 & 16 & 6 & 4.02 & 241 \\
\hline 2 & $\begin{array}{l}\text { Knowing what I know } \\
\text { now, if I had to decide all } \\
\text { over again whether to go } \\
\text { into pharmacy, I would } \\
\text { choose another field. }\end{array}$ & 62 & 43 & 36 & 60 & 39 & 3.12 & 240 \\
\hline 3 & $\begin{array}{l}\text { If I were free to pursue } \\
\text { any type of career I } \\
\text { wanted, I would stay in } \\
\text { pharmacy. }\end{array}$ & 68 & 80 & 57 & 21 & 14 & 3.70 & 240 \\
\hline & Average & & & & & & 3.61 & \\
\hline
\end{tabular}




\section{ABBREVIATIONS}

KSA: Kingdom of Saudi Arabia; MOH: Ministry of Health; B.Sc. Pharm: Bachelor in pharmacy; Pharm D: Doctor of Pharmacy; CBAHI: Saudi Central Board for Accreditation of Healthcare Institutions.

\section{ORCID ID}

Yousef Ahmed Alomi (iD https://orcid.org/0000-0003-1381-628X

\section{REFERENCES}

1. Almaghaslah D, Alsayari A, Asiri R, Albugami N. Pharmacy workforce in Saudi Arabia: Challenges and opportunities: A cross-sectional study. Int J Health Plann Manage. 2019;34(1):e583-93.
2. Iorga M, Dondas C, Soponaru C, Antofie I. Determinants of hospital pharmacists' job satisfaction in Romanian Hospitals. Pharmacy. 2017;5(4):66.

3. Carvajal MJ, Popovici I. Gender, age, and pharmacists' job satisfaction. Pharmacy Practice. 2018;16:1-11.

4. Porkelsson J. The impact of communication factors on job satisfaction among icelandic employees in the public sector. Reykjavík University. 2018.

5. Hincapie AL, Yandow S, Hines S, Martineau M, Warholak T. Job satisfaction among chain community pharmacists: Results from a pilot study. Pharm Pract. 2013;10(4):227-33

6. Slimane NSB. Motivation and job satisfaction of pharmacists in four hospitals in Saudi Arabia. J Health Manag. 2017;19(1):39-72.

7. Benslimane N, Khalifa M. Evaluating pharmacists' motivation and job satisfaction factors in Saudi Hospitals. Stud Health Technol Inform. 2016;226:201-4.

8. Balkhi B, Alghamdi A, Alshehri N, Alshehri A. Assessment of job satisfaction among hospital pharmacists in Saudi Arabia. IOSR J Pharm. 2017;7(5):34-40. 